\title{
CONTROL OF RAILROADS AFTER THE WAR
}

\section{Henry A. Palmer}

It might be asked why it should be assumed that there will be or should be a change after the war in the plan of railroad control in effect before the war. In other words, in what manner has the war-which has caused a temporary change to government operation to meet a serious emergency, but for that emergency onlymade it incumbent on the country to revise its method of regulating the common carriers? Most certainly it does not follow that, merely because there has been a change in methods to meet war conditions, there should be a permanent change. But just as certainly it is true that the exigencies of war have emphasized some of the weaknesses in our methods of regulation and that it would be folly not to cure them now that they have been so plainly exposed. And just as certainly it is true that the necessary war operation of the railroads by the government has demonstrated methods by which efficiency may be increased through their permanent application, and not to take advantage of this knowledge would be equally foolish. So, not as a natural consequence, but merely because we have already learned many ways in which our handling of the transportation problem may be improved, and will doubtless learn many more before the war is over, it does follow that after the war, when the railroads are returned as they should be to their owners, there must be some revision in the machinery by which they are regulated: this, both for their own benefit and that of the shipping public.

No one ought to attempt to say now with any degree of exactness what the after-the-war method should be. We are going through a historic period in railroad regulation and the experiment of government operation is as yet too new to justify any definite attempt at permanent application of the lessons learned-at least as long as there is so little prospect of an early end to the course of study. Whether we agree with what the government has done or not, it is done, and government operation will continue to the end of the war. We have all that time for observation and consideration as to what should be done when peace comes. Within a cer131 
tain definite period after the end of the war, government operation should cease and railroad control should automatically revert to the owners of the property. Then we should be prepared to enact, within that period, well considered, thoroughly scientific railroad regulation legislation, based not only on what was known before the war, but also on what we have learned while the war was in progress.

\section{Opinions Regarding Public Policy after War}

If government operation of the railroads during the war for the purpose for which they were taken over is a success-as it ought $\checkmark$ be and doubtless will be-there will be a great cry for government ownership. Already the preliminary notes have been heard. Of course, it does not at all follow that, because the government with the autocratic power given to the Director General of Railways in a war emergency can accomplish what the carriers themselves, hampered by law and custom and regard for the rights and comforts of their patrons, as well as for their own profits, could not accomplish, government ownership would be the proper nostrum. The arguments for and against such ownership are too well known to be entered into here. It is sufficient to say that the success of the government in accomplishing a war time task under war time powers at a cost of great sacrifice by commercial interests, would not be a legitimate added argument in its favor; while as an added argument against it is to be counted the fact that the government will hardly be in shape at the end of the war to assume such a huge financial burden.

As to whether there shall be some permanent plan of government control or operation short of actual ownership but akin to the present war plan, the question divides those who would put into effect a non-competitive system under government auspices from those who see no reason, because we have had a war, that the business methods of private ownership should not, in general, continue to govern. No one can dispute, of course, that if the government owned or controlled all the railroads and would work out and enforce an efficient plan; millions of dollars in duplicate salaries, duplicate trains, duplicate rents, duplicate service and facilities of all kinds could be saved. But they could also be saved if the government operated all the grocery stores, or all the coal mines, or all the churches. We may some time reach that Utopia but the time is 
not yet, either through government ownership or any other form of paternalism.

\section{Needed Reforms in Railroad Regulation}

Let us lay down, then, as the first general principle of the new system of regulation, that the railroads are to remain in private ownership, but with the added degree of government control that is necessary to the fair accomplishment of some of the reforms that seem to be wise. As the second, let us say that all laws that have hampered them in efficiency are to be repealed or amended so that, though injustice may not be done, the carriers will still be able to do things dictated by good business judgment which they are now prevented from doing. As the third, let us say that as far as possible or wise, all things considered, the railroads shall be compelled by law to do the things that have been demonstrated as efficient for them to do but which, of their own will, they have refrained from doing. In other words, let the railroads continue to operate under the same general plan of private control and ownership as before the war, with more liberality toward them as to the things they are permitted to do and greater strictness as to things they are compelled to do-which carries with it the idea of greater powers in some regulatory body, though those powers would be used for the carriers' benefit as well as for the repression of any improper desires on their part.

To start with, let us do away with the multiplicity of regulating bodies, the celebrated forty-nine masters, and center the regulating power in one federal body, the Interstate Commerce Commission. Let us do away with the state commissions as railway regulators except as they may continue to exercise mere police powers and, possibly, as they may continue to regulate railways that are purely intrastate. There are those who say this is not legally possible but there are others who say it is. But so far as it is legally possible it should be done and every effort should be made to determine its legal possibility. It is ridiculous and highly productive of inefficiency and unfairness that, for instance, a train must have one kind of crew in one state and a different kind in another; or that the fare should be fixed at one rate in one state and at a different rate in another, both, perhaps, varying from the interstate rate. The railroads, whatever their paper form of organization or what- 
ever the rights of states to regulate them, are a national system in reality and in so far as they are not permitted or compelled to operate as such they must fall short in efficiency.

It is true that this doctrine is shocking to some as an attempt to invade the sanctity of so-called state rights. But there is nothing sacred about the theory of state rights or any other political theory. If it does not hold water it should be cast aside. And, besides, there are those of no small ability and legal lore who hold that the doctrine of state rights is not incompatible with centralized federal regulation of railroads-indeed, that the two go hand in hand in that the real and highest right of a state is to be protected from discrimination by reason of the act of another state. These are questions for the lawyers, but they should be threshed out with a view to constructing an efficient system.

There must be a more definite government policy with respect to the revenue railroads are allowed to earn. As things are now, the Interstate Commerce Commission regulates rates-and the rate regulating power should remain in that body, war or no warbut there is always dispute and never certainty as to just how far the Commission may use its judgment in deciding whether the revenues of the carriers are sufficient. The inclination, in the absence of a definite declaration by Congress on the subject, is to confine consideration to the questions of reasonableness and discrimination. There should, perhaps, be fixed a minimum net return.

Even with such a provision we should be confronted by the vexed question of whether a certain general increase, which the weak roads need, should be allowed when it would swell the revenue of the more prosperous roads to unreasonable proportions. This brings us to the subject of the pooling of traffic and revenues, now illegal. It should be made legal, within certain limits. The stockholders of a given road should have reasonable assurance that, so long as the road was properly operated and necessary at all in the scheme of things, it would earn for them no less than a certain percentage of return. It might earn as much more as good management and general conditions warranted. Such a plan, to be sure, unless carefully worked out, might provide for the prosperous continuance of a road that really had no reason for living or for making money out of its existence. There would have to be government participation in deciding whether a given road should share in the 
promise of minimum return, and that power of participation would have to be wisely exercised. The strict rule of the survival of the fittest cannot be applied to the railroad situation for the reason that we have to take things as they are and not as they might be if we could start from nothing to build a new transportation scheme. Communities and businesses have grown up on the basis of the present system. They cannot be wiped out in the effort for absolute efficiency. The best that may be done is to empower an able commission to handle the situation with due regard for all existing interests to the end that necessary roads may not perish for lack of revenue but that those more fortunately situated may contribute somewhat of their prosperity. Doubtless repeal of the anti-pooling laws would accomplish all that is desired if the repealing act were accompanied by wise legislation safeguarding all interests. The first essential is to determine the policy. If it be the policy to enable our present railroads to continue to exist, and that by means of some plan which shall operate to distribute profits somewhat more equitably, and at the same time bring greater facility in the handling of the country's business by the pooling of traffic, then the rest is comparatively easy, a matter of detail. Such a plan would not be solely nor even chiefly for the benefit of the carriers. The shipping public would profit. Rates would probably be no higher than they otherwise would be and service would be better.

\section{Pooling of Facilities}

The pooling, or common use, of railroad facilities is already legal and was tried even before the government took over the roads with some degree of success by the eastern carriers. It should be made compulsory, within proper limits. The purpose of transportation is to get freight and passengers moved and the reason for congestion is that they are not moved. If we are to consider transportation nationally there is no reason why a road possessing facilities that will help in the moving of this traffic should not be compelled to permit their use to the utmost by anybody that can use them for the necessary purpose, provided, of course, that the rights of the owner to due compensation are protected. It might be urged that if a given railroad knew that some facility it might build-a new terminal, for instance - could be used by any road that wished to use it, it might refrain from building it. But here the govern- 
ment should take a hand. When facilities are needed it should compel the railroads to provide them, and there would be no hardship or injustice in its doing so as long as it provided for the necessary revenue.

The one great transportation lesson of this war is that the railroads have not kept pace in the matter of rolling stock and terminal facilities with the growing needs of the country, even aside from the war emergency. They must be made to do so, for in the sense that transportation is a commodity to which the public is entitled at reasonable rates, the railroads cannot be operated as a private business. But they cannot be expected or even compelled to do so unless their income is sufficient to justify the necessary expenditures. Rates and service to the public are coördinate questions and must be handled by the same authority in accordance with a well defined policy.

As a means of bringing about more expeditious loading and unloading of cars by shippers and consignees, higher demurrage charges are being tried by order of the Director General of Railways and the Interstate Commerce Commission. In so far as they achieve the object desired they are perfectly proper. The question of propriety is merely one of efficacy. There is as yet no scientific system of such charges for that purpose. There should be one, and now is the time to make the preliminary study.

\section{Speed In Moving Freight}

But while penalizing the shipper and the consignee for failure to reach efficiency in their part of the transportation operation, why not compel the carriers, by some similar system of penalties, to move freight more promptly? No inconsiderable part of the delay resulting in demurrage is attributable to the faults of the carriers themselves. Figures are easily obtainable showing the unreasonable time consumed in transit and the same is true with regard to delays at terminals. Daniel Willard, president of the Baltimore and Ohio railroad, has pointed out that 52 per cent of the time of a freight car is wasted around terminals and that it is moving on the road only 11 per cent of its time. When from this 11 per cent is deducted the time wasted in slow movement, the freight car as a medium of transportation does not make much of a showing.

Mr. Willard's statement was made last July. Doubtless the 
showing was in great measure due to the tangle brought on by the war congestion, but not all of it was thus due. There is, perhaps, no greater field for improvement in transportation than in the movement of freight cars, and shippers complain greatly at being held up by the reformers as horrible examples when they know that the railroads themselves are at least as greatly to blame. The government, by its authorized system of penalties, compels or tries to compel the shipper to be efficient. It should exercise the same degree of compulsion toward the carrier.

There should be a clearer determination as to the rights and duties of carriers in the matter of embargo, as to when an embargo may be declared and what notice shall be given, both to other roads affected and to shippers. The practice is loose and productive of much confusion and dissatisfaction.

A. H. Smith, eastern assistant to the Director General, recently instructed eastern roads to embargo consignees who do not unload cars promptly, regardless of demurrage rules. This is an order perhaps necessary and proper under war operation, if it is carried out under the direction of government authorities, but there is nothing in law to prevent such an embargo at the will of the railroads in ordinary times when, in their opinion, necessity requires it. Probably there are few railroad men whose judgment could be depended on in a matter of that kind, and even if the motive were admittedly proper the shipper is entitled to know that he has recourse and that his interests are protected.

Another result of war operation of the railroads has been the overriding of the law giving to the shipper the right to direct the routing of his freight. It is certainly in the interest of efficiency that this be done, though perhaps the Director General exceeded his legal power in doing it. Perhaps the right ought permanently to be taken away by law within certain limits. The shipper ought, no doubt, to be permitted to control delivery. That is, though freight should be sent by way of the route most likely to afford expeditious movement and not by the route some persuasive agent has induced the shipper to select, the shipper ought to be protected to the extent that the freight will be switched without cost to him to the road on which he has his place of business or sidetrack, from the road which has been selected as the most expeditious route.

There should be provision for compulsory arbitration of wage 
demands which would carry with it a practically automatic increase in rates to meet the wage increase when such an increase is permitted or ordered by the government. Another performance like the clubbing through Congress by the labor unions of the Adamson eight-hour wage law, leaving the railroads to find, as best they may, the money to meet the increase, should be made impossible.

Still another reform that has been many times urged and generally overlooked, apparently because it is held of comparatively slight importance, is the giving to the shipper right to appeal from negative orders of the Interstate Commerce Commission. Important or not, it is his right, or should be, and should be given him for the asking. The less important it is the less trouble it would be to grant it.

There has been no attempt herein to outline any dogmatic plan for a reorganization of the plan of railroad control. Not only is the future of the railroads uncertain but it is not altogether certain what that future should be. The attempt has been merely to suggest some changes that would appear at this time to be wise. 